\title{
Edukacja wspierająca rozwój młodzieży \\ i jej uwarunkowania - \\ raport z badań na pograniczu południowym
}

\begin{abstract}
STRESZCZENIE
Tekst ten włącza się w debatę nad zadaniami pedagogiki, edukacji na rzecz wspierania rozwoju młodzieży. Jego celem jest prezentacja wiedzy i doświadczeń badawczych nad zadaniami rozwojowymi i pograniczem oraz pobudzanie do dyskusji, której rezultatem może być bardziej świadome ujmowanie i wykorzystywanie tych kategorii w pedagogice. Autorka przedstawia raport z badań młodzieży na pograniczu południowym. Wyniki tych badań, w dwóch okresach pomiarowych, wskazały z jednej strony na względne podobieństwo zadań rozwojowych, konstruowania tożsamości młodzieży żyjącej na pograniczu południowym, z drugiej zaś - na różnice w poziomie ich wypełniania. Wypełnianie zadań rozwojowych, konstruowanie tożsamości młodzieży i ich uwarunkowania to ważny obszar pedagogiki. Pozwala na rozpoznanie rzeczywistych barier rozwoju indywidualnego w płaszczyźnie społecznej i kulturowej oraz skutecznych czy też nieskutecznych strategii ich przekraczania.
\end{abstract}

\section{Słowa kluczowe:}

młodzież, zadania rozwojowe, tożsamość, edukacja, pogranicze

1 Alina Szczurek-Boruta, Wydział Etnologii i Nauk o Edukacji, Uniwersytet Śląski w Katowicach, Polska, alina.szczurek-boruta@us.edu.pl. 


\begin{abstract}
The undertaken study is aimed at presenting the knowledge and research experiences concerning developmental tasks and the borderland, as well as stimulating the discussion which might result in a more conscious approach and application of these categories in the context of pedagogy. The author presents a report from some studies conducted in the Southern borderland. The text becomes a part of the debate on the tasks of pedagogy - the education aimed at supporting the development of youth. The research into fulfilling developmental tasks, shaping youth's identity and its many determinants constitute an important field of pedagogy. These studies enable the recognition of the real barriers for individual development in the social and cultural dimension, as well as the efficient or inefficient strategies of overcoming them.
\end{abstract}

\title{
Keywords:
}

youth, developmental tasks, identity, education, borderland

\section{WPROWADZENIE}

Tekst ten włącza się w debatę nad zadaniami pedagogiki, edukacji na rzecz wspierania rozwoju osób „przechodzących przez młodość”. Celem podjętych rozważań jest prezentacja wiedzy i doświadczeń badawczych nad zadaniami rozwojowymi i pograniczem oraz pobudzanie do dyskusji, której rezultatem może być bardziej świadome ujmowanie i wykorzystywanie tych kategorii w kontekście pedagogiki.

Zrozumienie zadań rozwojowych jest niezbędne do mądrej regulacji funkcjonowania instytucji oświatowych i ich skutecznego działania na rzecz dzieci i młodzieży. Nauczycielom przydatne jest do lepszego pojmowania swego warsztatu i środków działania, a specjalistom i samorządowcom zarówno do umiejętnego wykorzystania w prowadzonej polityce społecznej, oświatowej, jak i do umacniania zaufania do instytucji, jaką jest szkoła.

Kategoria pogranicza służy do wyjaśnienia i ukazania kontekstu społeczno-kulturowego kondycji jednostki, konstruowania tożsamości. Takie myślenie jest obecne w psychologii społeczno-kulturowego pogranicza (Miluska, 2016), socjologii (Sadowski 1992; Golka 2016), w pedagogice (Lewowicki, 1994; Nikitorowicz 1995). W moim przekonaniu, popartym wynikami badań, warto wzmocnić wagę tego myślenia i wskazać na pedagogiczną wartość pogranicza jako stymulatora rozwoju jednostek, grup, wyznacznika procesów socjalizacji i wychowania związanych ze specyficznym terenem. 


\section{ZAŁOŻENIA TEORETYCZNE}

Zadanie jako kategoria poznawcza występuje głównie w dociekaniach psychologicznych w kontekście aktywności (Tomaszewski, 1966, s. 197-252; Reber, 2002, s. 867-868; Cole, Hall, 1964, s. 6-7), problemów, które rozwijająca/rosnąca osoba musi rozwiązać (Thomas, ed. 1990, p. 118-120; The Encyclopedia Britannica 2002; Compact Oxford English Dictionary of Current English), zadań witalnych, egzystencjalnych (Erikson, 1994), zadań rozwojowych Havighursta (Brzezińska 2000; Malina, 2015 itp.). W ujęciu socjologicznym dostrzega się znaczenie wypełniania zadań rozwojowych zapewniających zarówno trwałość, ciągłość, jak i zmiany społeczne (Hurrelmann, 1994).

W pedagogice kategoria ta rozpatrywana jest jako: specyficzny wzorzec wymogów zachowań charakterystycznych dla określonej fazy życia; czynnik konstrukcyjny, określający strukturę rzeczywistości edukacyjnej oraz wartościujący opisywane zjawiska wychowania. Wpisuje się ona w krytyczno-kreatywną doktrynę edukacyjną, wysuwającą na pierwszy plan kształtowanie postaw, umiejętności, na końcu wiadomości (Szczurek-Boruta, 2007, 2008).

Zadania rozwojowe przedstawiają definicję naszej kultury, swoisty kod kulturowy (Szczurek-Boruta, 2007, 2008). Rola kultury w formowaniu wzorów zachowania się ludzi jest powszechnie rozumiana i doceniana w psychologii (Przetacznikowa-Gierowska, 2002). Doświadczenia młodego człowieka zdobywane są przez niego i rozpatrywane w społeczno-kulturowym kontekście życia (Tyszkowa, 1988; Brzezińska, 2000; Hurlock, 1985; Triandis, 1991; Price, Crapo, 2003). W socjalizacji w ramach odrębnej kultury widzi się swoiste zaprogramowanie jednostki oraz grupy społecznej (Hofstede, 2000). Znaczenie wartości kulturowych, jak i instytucjonalnych w kształtowaniu się ludzkich zachowań podkreślają socjologowie (Parsons 1969; Merton, 1982; Bauman, 1996). Całościową analizę zjawisk kulturowych i społecznych postulują Antonina Kłoskowska (1983), Leon Dyczewski (2003), Piotr Sztompka (1989).

W prowadzonych poczynaniach badawczych stosuję podejście eklektyczne. Odwołuję się do teorii rozwoju psychospołecznego E. Eriksona (1994), koncepcji zadań rozwojowych R. Havighursta (1972, 1981), Teorii Zachowań Tożsamościowych TZT T. Lewowickiego (1995). Przyjmuję, że „dominującym zadaniem egzystencjalnym $\mathrm{V}$ fazy (adolescencji) jest zaspokojenie potrzeby tożsamości (...) Każdemu zadaniu egzystencjalnemu można przypisać kulturowo akceptowane formy realizacji (rytualizacji) - zadania rozwojowe. (...) Ponieważ empiryczny ekwiwalent zadań rozwojowych nie ma charakteru bezpośredniego, a obserwowane drogi realizacji zadania egzystencjalnego przejawiają się w kulturowo akcep- 
towanych sposobach doświadczania i zachowania się wobec innych przyjęto, że przejawem (empirycznym wskaźnikiem) poczucia realizacji zadania rozwojowego są zachowania tożsamościowe (w myśl teorii Lewowickiego pozwalające identyfikować tożsamość, manifestować ją, zabiegać o trwanie i korzystne przemiany) (Szczurek-Boruta 2007, s. 155).

Wiedza i namysł nad wypełnianiem zadań rozwojowych, konstruowaniem tożsamości młodzieży i ich uwarunkowaniami to - w moim przekonaniu - ważny obszar pedagogiki. Pozwala bowiem na rozpoznanie rzeczywistych barier rozwoju indywidualnego w płaszczyźnie społecznej i kulturowej oraz skutecznych czy też nieskutecznych strategii ich przekraczania. Istotnie, w kontekście prowadzonych rozważań znaczenie przypisuję społeczno-kulturowemu pograniczu. Zachowania, wzory działania, wartości, indywidualne przekonania i pragnienia są bowiem funkcją istniejącego kontekstu społeczno-kulturowego.

\section{ZAŁOŻENIA METODOLOGICZNE BADAŃ WŁASNYCH}

Prezentowane badania są częścią szerszych badań ilościowych i jakościowych młodzieży i edukacji szkolnej. Ich przedmiotem są tożsamość, zadania rozwojowe młodzieży i determinanty ich opanowywania. Celem - diagnoza opanowania zadań rozwojowych przez młodzież i określenie warunków ich wypełniania w środowisku zróżnicowanym społecznie, kulturowo i gospodarczo na pograniczu południowym.

Stawiam tezę, iż pogranicze stymuluje rozwój indywidualny, społeczny młodzieży, stwarza warunki do realizacji zadania egzystencjalnego, którym jest zaspokojenie potrzeby tożsamości, stanowi specyficzne „pole” (wielość rzeczywistości i ich konstruowanie, struktura/struktury, w których działają ludzie) o określonym kapitale (społecznym, kulturowym, ludzkim), zapewnia trwałość, ciągłość (dostarcza źródeł i podstaw do konstruowania tożsamości), jest też źródłem zmiany społecznej. Wytworzyło ono schematy mentalne i dyspozycje do działań zinternalizowane przez jednostkę. Z tego zasobu korzysta nie tylko jednostka w swoich działaniach, ale i instytucje edukacyjne, społeczno-kulturalne. Życie na pograniczu stymuluje rozwój, stwarza warunki sprzyjające realizacji, ćwiczeniu, przepracowywaniu zadań rozwojowych przez młodych ludzi. Pogranicze warunkuje procesy socjalizacji i wychowania.

W pracy badawczej poszukiwano odpowiedzi na trzy kluczowe pytania:

1. Jakie, w poczuciu młodzieży (18-latków w roku szkolnym 2016/2017), zadania rozwojowe są lepiej lub gorzej opanowywane? 
2. Jakie są podobieństwa i różnice w średnich wynikach opanowania poszczególnych zadań przez 18-latków w roku szkolnym 2003/2004 i 18-latków w roku 2016/2017?

3. Czy - i ewentualnie jaki - istnieje związek między społecznymi warunkami edukacji a kształtowaniem się tożsamości młodzieży?

Niniejsze badania mieszczą się w schemacie porównawczym, prowadzono je w oparciu o strategię ilościową, a wyjaśnienia, jakie uzyskano mają charakter nomotetyczny, oparto je na przesłankach obiektywistycznych, dotyczących paradygmatu normatywnego. Zastosowano badania sondażowe (Frankfort-Nachmias, Nachmias, 2001: 153-154). Przeprowadzono je przy użyciu autorskiego kwestionariusza ankiety opartego na teorii rozwoju psychospołecznego E. Eriksona, koncepcji zadań rozwojowych R. Havighursta i TZT T. Lewowickiego, socjologicznych teoriach konfliktu. W badaniach wykorzystano narzędzie własnej konstrukcji zweryfikowane we wcześniejszych badaniach ${ }^{2}$. Kwestionariusz ankiety zawiera 48 pytań w części A (zadania rozwojowe), 41 pytań w części B (społeczne warunki edukacji). Metryczka ankiety to osiem pytań (kwestionariusz zamieszczony w pracy A. Szczurek-Boruta, 2007, s. 381-384).

Zastosowano strategię badań ukośnych ${ }^{3}$, przeprowadzono pomiar danej zmiennej (zadań rozwojowych i społecznych warunków edukacji) tym samym narzędziem (autorski kwestionariusz ankiety wykorzystany po raz pierwszy w 2003 r.), w sposób powtarzalny w różnym czasie (w roku szkolnym 2003/20044 i w roku szkolnym 2016/20175), na tej samej kohordzie (do grupy zwanej kohortą zaliczono osoby w wieku adolescencji). Osoby badane reprezentowały ten sam poziom wieku 18 lat.

Próba badana dobrana została metodą celowo-losową (Matuszak, Matuszak 2011, s. 33-39). Elementy celowe to: wiek uczniów - 18 lat; typ szkoły - szkoła (technikum/liceum), miejsce zamieszkania - pogranicze południowe. Badana grupa w dwóch okresach pomiarowych spełniała kryteria próby reprezentatywnej.

Zgromadzony materiał badawczy poddany został weryfikacji z wykorzystaniem metod ilościowego i jakościowego opisu badań.

2 Współczynnik rzetelności, alfa ( $\alpha$ ) Cronbacha 0,730 (w przedziale 0-1) potwierdza prawidłową konstrukcję kwestionariusza (Szczurek-Boruta, 2007, s. 178-183).

3 W badaniach nad rozwojem psychicznym stosowane są trzy tradycyjne strategie: poprzeczne, podłużne i ukośne (za: Trempała, Olejnik, 2016, s. 134-135).

4 Opis badanej grupy (195 uczniów) w roku szkolnym 2003/2004 oraz metodologii badań w opracowaniu: Szczurek-Boruta, 2007.

5 W roku szkolnym 2016/2017 w badaniach uczestniczyło 248 uczniów: 112 kobiet i 136 mężczyzn, 185 uczniów technikum oraz 63 uczniów liceum. 
W opracowaniu uzyskanych danych empirycznych zastosowane zostały metody statystyczne: testowanie statystycznej istotności różnic między zmiennymi za pomocą testu Chi - kwadrat $\left(\mathrm{x}^{2}\right)$, analiza kanoniczna oraz statystyki opisowe (Ferguson, Takane, 2004). Zastosowano program do analizy statystycznej zawarty w komputerowym pakiecie STATISTICA 13.

\section{ANALIZA I INTERPRETACJA WYNIKÓW BADANIA}

Celem poznawczym podjętych badań jest określenie przepracowania, wykonania zadania edukacyjnego, którym jest tożsamość. Bardziej szczegółowym celem jest diagnoza opanowania poszczególnych zadań rozwojowych przez adolescentów.

W prezentowanych analizach wykorzystano tylko część materiału empirycznego uzyskanego w autorskich ogólnopolskich badaniach przeprowadzonych w roku szkolnym 2003/2004, a mianowicie wyniki badań ilościowych młodzieży z pogranicza południowego, strefy o wysokim potencjale społeczno-gospodarczym oraz część materiału pochodzącego z badań przeprowadzonych w roku 2016/2017.

Opanowanie (realizacja) zadania egzystencjalnego (zaspokojenie potrzeby tożsamości) wiąże się z koniecznością syntezy (opanowania) różnych szczegółowych zadań rozwojowych. W badaniach wykorzystano listę 10 empirycznie zweryfikowanych zadań rozwojowych. Przyjęto, że przejawem poczucia realizacji zadań rozwojowych są deklarowane zachowania tożsamościowe (subiektywne odczucia jednostki, co do poczucia występowania określonych faktów, zdarzeń, sytuacji, pozwalające identyfikować tożsamość, manifestować ją, zabiegać o jej trwanie i przemiany).

Analizie eksploracyjnej i porównawczej poddano zadania rozwojowe oraz społeczne warunki edukacji ${ }^{6}$. Za podstawę analiz przyjęto przede wszystkim ustosunkowanie się badanych do stwierdzeń zawartych w kwestionariuszu ankiety.

W badaniach przeprowadzonych w roku szkolnym 2016/2017 pośród 10 zadań rozwojowych, osiem osiągnęło najwyższe średnie w populacji badanych, a dwa zadania nie były realizowane ${ }^{7}$. Najważniejszymi zadaniami rozwojowymi w od-

6 Do społecznych warunków edukacji zaliczono: „dostarczanie oferty identyfikacyjnej”, „przedłużanie moratorium rozwojowego”, „poszerzanie promienia interakcji”, „etos”, , ,ambiwalencję”, „rewitalizację”.

7 Wyniki interpretowane są w zakresie poszczególnych zadań. W tym celu zsumowano wagi przypisywane poszczególnym odpowiedziom. Za odpowiedź diagnostyczną osoba badana otrzymywała trzy, za niediagnostyczną jeden punkt, a dwa punkty za odpowiedź „nie wiem”. Odpowiedzią diagnostyczną w przypadku zadań A1, A2, A3, A4, A5, A6, A7, A9, A10 była „prawda”, a w przy- 
czuciu młodzieży są kolejno: „opanowanie roli społecznej właściwej dla swojej płci” A2 ( $\bar{x}=2,55)$; „osiąganie niezależności emocjonalnej i ekonomicznej od innych” A4 ( $\bar{x}=2,51)$; ,„poszukiwanie partnera życiowego - miłości” A3 ( $\bar{x}=2,45)$; „ustalenie systemu wartości” A10 ( $\bar{x}=2,42)$; „wybór i przygotowanie do zawodu” A7 ( $\bar{x}=2,38)$; „osiąganie dojrzalszych relacji z grupą przyjaciół - rówieśników” A1 ( $\bar{x}=2,28)$; , uzyskanie wiedzy o sobie” A5 ( $\bar{x}=2,22)$; „osiąganie kompetencji w realizacji zadań szkolnych” A6 $(\bar{x}=2,19)$. Wyróżnią się one wyjątkową wysokością wskaźników poczucia opanowania, przepracowania, wypełniania. Uzyskały najwyższe średnie wskaźniki przepracowania z przedziału od 2,0 do 3,0.

Odnotowano wzrost średniej wartości opanowania przez młodzież dwóch zadań: „opanowanie roli społecznej właściwej dla swojej płci” A2 (jest $\bar{x}=2,55$, było $\bar{x}=2,26$, zmiana 12,5\%) oraz ,uzyskanie wiedzy o sobie” A5 (jest $\bar{x}=2,22$, było $\bar{x}=2,14$, zmiana 3,5\%) (wykres 1). Tożsamość płciowa jest jedną z najważniejszych form tożsamości społecznej (Oleszkowicz, Senejko, 2016, s. 261). Zmiany w obrazie ciała i strukturze potrzeb traktowane są jako dowód statusu osoby dorosłej i stają się podstawą do dalszego budowania koncepcji Ja, z tego względu jest to zasadnicze zadanie rozwojowe w tym okresie, a dla otoczenia stanowi sygnał wyzwalający oczekiwania społeczne wobec jednostki w zakresie pełnienia przez nią ról związanych z płcią. Młodym ludziom zależy na rozwoju Ja, dochodzeniu do tożsamości. Generalnie bardziej koncentrują się na osobistych celach związanych z intymnością, wiedzy o sobie, niezależności emocjonalnej i finansowej od rodziców. Koncentracja na sobie, własnych celach i wartościach wewnętrznych to jedna z cech dystynktywnych właściwa wielu fazom życia także opisująca okres stającej się dorosłości (Hartmann, Toguchi Swartz, 2018).

Zauważyć można (w dwóch okresach pomiarowych) spadek poziomu realizacji dwóch zadań: „osiąganie dojrzalszych relacji z grupą przyjaciół - rówieśników” A1 (jest $\bar{x}=2,28$, było $\bar{x}=2,68$, zmiana $-14,8 \%$ ) oraz ,osiąganie kompetencji w realizacji zadań szkolnych” A6 (jest $\bar{x}=2,19$, było $\bar{x}=2,35$, zmiana $-6,7 \%$ ). Wyniki potwierdzają opinie socjologów o słabnących w społeczeństwie polskim więziach subiektywnych (Sztompka, 2002, s. 190). Młodzi ludzie to użytkownicy sieci, wirtualnych społeczności, zwolennicy mediów społecznościowych, przestrzeń wirtualna to ich dom, stają się jej więźniami (Gobal-Klas, 2009). Coraz gorzej radzą sobie w relacjach bezpośrednich face to face, co rodzi poważne zagrożenia

padku zadania rozwojowego A8 „fałsz”. Średnie wielkości poczucia opanowania większości zadań rozwojowych przez młodzież $(\bar{x})$ mieszczą się w przedziale 1-3 (przy punktacji 1 - fałsz, 2 - nie wiem, 3 - prawda), przyjmują wartość powyżej 2,0 (średnią 2,0 uznano za próg opanowania zadań). Dla badanej populacji obliczono udział procentowy osób, dla których przejawem poczucia realizacji określonego zadania były wyróżnione zachowania tożsamościowe. 
i następstwa: samotność, depresja, samobójstwa wśród młodzieży i stanowi wyzwanie dla pedagogiki.

Coraz większe wymagania względem uczniów skutkują słabszą motywacją do nauki i mniejszym poczuciem kompetencji w realizacji zadań szkolnych. Spadek poczucia własnej skuteczności może być też związany ze zbiegiem deprymujących okoliczności, np. pesymistyczne prognozy poradzenia sobie z przyszłymi trudnościami (egzamin dojrzałości), spadkiem zaufania do swoich możliwości. Nowe zmediatyzowane społeczeństwo rodzi nowy typ człowieka: „obecne pokolenie jest pokoleniem ekranowym (ang. screeny generation), Video Generation, traktującym obraz jako środek przekazu równorzędny przekazom książkowym, a nawet lepszy, bo prostszy i atrakcyjniejszy” (Global-Klas, 2009, s. 299). Ma to poważne konsekwencje dla konstruowania tożsamości i edukacji (Krzysztofek, Szczepański, 2003; Melosik 2013).

średnia 2003/2004
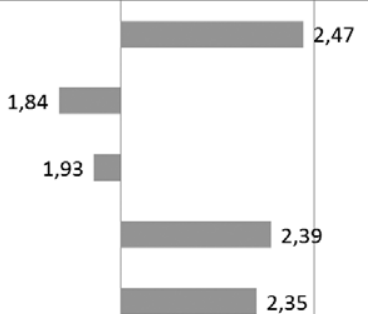

2,14

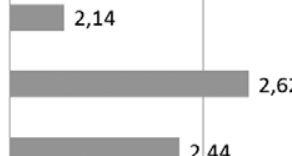

2,26 zmiana [\%]

średnia 2016/2017

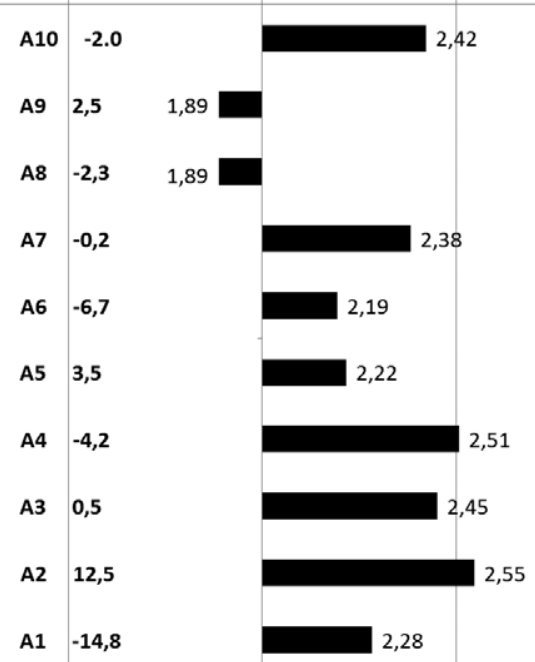

Wykres 1. Dynamika realizacji zadań rozwojowych przez 18-latków w roku szkolnym 2003/2004 roku i 18-latków w roku 2016/2017

Legenda: A1 „osiąganie dojrzalszych relacji z grupą przyjaciół - rówieśników”; A2 „opanowanie roli społecznej właściwej dla swojej płci”; A3 „poszukiwanie partnera życiowego - miłości”; A4 „osiąganie niezależności emocjonalnej i ekonomicznej od innych”; A5 „uzyskanie wiedzy o sobie”; A6 „osiąganie kompetencji w realizacji zadań szkolnych”; A7 „wybór i przygotowanie do zawodu”; A8 „rozumienie zjawisk świata społecznego (bezrobocie, polityka, ekonomia) jako przygotowanie do pełnienia ról obywatelskich”; A9 „zmiana i kształtowanie otaczającej rzeczywistości”; A10 „ustalenie systemu wartości”.

Źródło: badania własne. 
Na podobnym poziomie (w dwóch okresach pomiarowych) pozostają dwa zadania „poszukiwanie partnera życiowego - miłości” A3 (jest $\bar{x}=2,45$, było $\bar{x}=2,40$, zmiana $0,5 \%$ ), oraz , wybór i przygotowanie do zawodu” A7 (jest $\bar{x}=2,38$, było $\bar{x}=2,39$, zmiana $-0,2 \%)$.

W badaniach ustalono, że dwa zadania: „,rozumienie zjawisk świata społecznego (bezrobocie, polityka, ekonomia) jako przygotowanie do pełnienia ról obywatelskich” A8 (jest $\bar{x}=1,89$, było $\bar{x}=1,93$, zmiana $-2,3 \%$ ) oraz ,zmiana i kształtowanie otaczającej rzeczywistości” A9 (jest $\bar{x}=1,89$, było $\bar{x}=1,84$, zmiana $2,5 \%$ ) nie były i nie są wypełniane przez młodzież. Nieznacznie spadło poczucie rozumienia zjawisk świata społecznego. Niewielki wzrost realizacji - w stosunku do wyników badań wcześniejszych - odnotowano w zakresie zmiany i kształtowania otaczającej rzeczywistości. W przypadku tych dwóch zadań zauważyć można brak wyraźnego wsparcia w ich przepracowywaniu przez szkołę i środowisko. Społeczeństwo jest zbyt ubogie w takie programy kształcenia, które w sensie pragmatycznym przybliżyłyby dorastających do problemów funkcjonowania w świecie społecznym. Być może w tym tkwi niezgodność pomiędzy usytuowaniem tych zadań przez młodzież w okresie dorastania i przesunięciem ich realizacji na fazy następne. Wyniki badań ilustrują niezmienną od lat tendencję kurczenia się kapitału społecznego, społeczeństwo staje się mniej ufne, coraz rzadziej przejawia postawy obywatelskie (Putnam, 2008).

Młodych ludzi cechuje sceptycyzm wobec jakiegokolwiek zaangażowania się głębszego uczestnictwa. W sytuacji braku jasnych odpowiedzi na postawione pytania egzystencjalne, w kulturze pełnej sprzeczności, konieczności nieustannej adaptacji (Melosik, 2013), prymatu indywidualizmu nad kolektywizmem (Cybal-Michalska, 2006, 2013) brak zaangażowania stanowi warunek kulturowego przetrwania (na fakt ten zwracał uwagę już w latach 90. Grossberg (1989), pisząc o globalnym nastolatku).

Opanowanie zadań rozwojowych fazy adolescencji wskazuje na realizację zadania egzystencjalnego, którym jest zaspokojenie potrzeby tożsamości. Na podstawie poczucia opanowania przez młodzież zadań rozwojowych wnioskować można zatem o tożsamości i jej konstruowaniu, o kondycji i rozwoju jednostki.

Przeprowadzone analizy statystyczne pozwalają stwierdzić, że w roku szkolnym 2003/2004 średnia wielkość poczucia opanowania zadań rozwojowych (A1 do A10) - tożsamości (A) wynosiła $(\bar{x}=2,33)$, w badaniach przeprowadzonych w roku 2016/2017 średnia wynosiła $(\bar{x}=2,28)$. Oba wyniki są bardzo zbliżone, zmiana $2 \%$ jest nieznaczna.

Wyniki przeprowadzonych badań, w dwóch okresach pomiarowych, wskazały z jednej strony na względne podobieństwo wypełniania zadań rozwojowych, 
konstruowania tożsamości przez 18-latków żyjących na pograniczu południowym, w strefie o intensywnym rozwoju społeczno-gospodarczym, z drugiej zaś - na różnice w poziomie ich wypełniania.

Osoby badane w roku szkolnym 2003/2004 to osoby urodzone w połowie lat 90., zaś badane w roku 2016/2017 urodziły się pod koniec XX w. Umysł tego młodego pokolenia/pokoleń Y i Z (Generation XYX, 2018) jest kulturowo zaprogramowany przez media, które dostarczają schematów, norm, kryteriów. Młodzi ludzie podlegają tej samej uniwersalnej logice rozwoju jako istoty żywe (zgodność rozwoju z prawami natury) i jako istoty społeczne, żyjące pośród innych ludzi. Ich dziecińsko przypada na czas społeczeństwa informacyjnego (Beniger, 1986), społeczeństwa sieciowego (Castells, 1998), społeczeństwa medialnego (Thompson 1999), wieku dostępu (Rifkin, 2000). Jednocześnie każdego człowieka charakteryzuje jego własna niepowtarzalna, indywidualna logika rozwoju, związana z tym, że każdy inaczej postrzega, interpretuje i przeżywa różne sytuacje w swym życiu, każdy ma swoją własną definicję sytuacji, w której przychodzi mu działać.

Na uzyskane wyniki warto spojrzeć przez pryzmat miejsca, które jest ważnym wymiarem tożsamości (Castells, 2008; Muszyńska, 2014). Istnieje bogata literatura etnograficzna i etnologiczna, socjologiczna dokumentująca charakter południowego pogranicza (m.in. Świątkiewicz, 1992; Bazielich, 1995; Szczepański 1999, s. 161-180). Jest to swoisty tygiel kulturowy z oazami tradycyjnej, pielęgnowanej i hołubionej kultury, obszar o wyraźnie zaznaczonej tożsamości (Gładysz, 1972, s. 7-41; Lipok-Bierwiaczonek, 1994; Szczepański, 1999, s. 161-180). Specyfika tego pogranicza i jego kulturowe atrybuty warunkują konstruowanie się tożsamości jego mieszkańców. Z uwagi na ograniczoną objętość tego opracowania nie będę szczegółowo opisywała tych kwestii.

Pogranicze południowe dostarczało i dostarcza młodym ludziom źródeł i podstaw do konstruowania tożsamości (por. warunki socjalizacyjne konstruowania tożsamości opisywane m.in. w pracach: Lewowicki 1994; Jasiński, Lewowicki, Nikitorowicz, 1998; Lewowicki, Ogrodzka-Mazur, Szczurek-Boruta, 2009). Miejsce kształtuje schematy poznawcze, ćwiczy w przepracowywaniu zadań rozwojowych, dostarcza doświadczeń w kontaktach międzyludzkich. Różnorodność pogranicza jest wartością autoteliczną, jej realizacja jest dobrem samym w sobie, sprzyja rozwojowi. Podkreślić należy też wagę ustawicznego uczenia się, którego istotą jest rozumienie. 


\section{UWARUNKOWANIA KSZTAŁTOWANIA SIĘ TOŻSAMOŚCI MŁODZIEŻY}

Wyniki przeprowadzonych badań wskazują na efekt płci w zakresie poczucia wypełniania zadań rozwojowych - tożsamości. Związek pomiędzy płcią a wypełnianiem zadań rozwojowych A $(r=0,520 ; \mathrm{p}<0,000)$, wskazuje na zależność wyraźną, choć małą . Istotny wpływ płci psychologicznej na sposób i jakość funkcjonowania człowieka potwierdzają wyniki licznych badań (m.in. Miluska, 1996; Brzezińska, Bardziejewska, Ziółkowska, 2003).

Wyraźna korelacja występuje między typem szkoły (technikum, liceum) a wypełnianiem zadań rozwojowych A $(\mathrm{r}=0,418 ; \mathrm{p}<0,002)$, szczególnie dotyczy to zadań: A7 „wybór i przygotowanie do zawodu”; A8 „rozumienie zjawisk świata społecznego (bezrobocie, polityka, ekonomia) jako przygotowanie do pełnienia ról obywatelskich”; A9 „zmiana i kształtowanie otaczającej rzeczywistości”; A10 „ustalenie systemu wartości”.

Młodzi ludzie szkołę traktują jako etap, w którym adaptują się do jej warunków, podporządkowują wymaganiom, bo cel jest jeden - przygotować się do egzaminu maturalnego i go zdać. Są w stanie wiele poświęcić, by to zadanie zrealizować. Istotny udział w tym przejściu - jak pokazały wyniki badań - ma określony typ instytucji oświatowej. Technikum efektywnie łączy teorię z praktyką, daje większe możliwości gromadzenia doświadczeń, spełniania się w realnych sytuacjach, podnoszenia kompetencji zwłaszcza zawodowych.

Wypełnianie zadań rozwojowych nie jest możliwe bez zewnętrznego wsparcia w postaci naturalnych i intencjonalnych oddziaływań wychowawczych. W centrum zainteresowań badawczych umieszczono społeczne warunki edukacji (sytuacje rozwoju, zdarzenia, fakty, układ ludzi dostarczający różnorodnych doświadczeń), oddziałujące na przepracowywanie przez młodzież zadań rozwojowych. W tym planie badań podjęto próbę określenia warunków („dostarczanie oferty identyfikacyjnej”, „przedłużanie moratorium rozwojowego”, „poszerzanie promienia interakcji”, „etos”, „ambiwalencja”, „rewitalizacja”), które muszą być spełnione, by rozwój jednostki przebiegał prawidłowo. Owe warunki (kategorie pojęciowe zaczerpnęłam z teorii E. Eriksona) potraktowałam jako specyficzne zadania edukacyjne, ukierunkowujące i uruchamiające działania, których wynikiem są określone rezultaty, zaznaczające się zarówno w samym podmiocie działania

8 Interpretacja wielkości współczynników korelacji r wg J.P. Guilforda (1960, s. 171). Poniżej 0,20 - korelacja słaba, zależność prawie nic nie znacząca; 0,20-0,40 - korelacja niska, zależność wyraźna, lecz mała; 0,40-0,70 - korelacja umiarkowana, zależność istotna; 0,70-0,90 - korelacja wysoka, zależność znacząca; 0,90-1,00 - korelacja bardzo wysoka, zależność bardzo pewna. 
(opanowanie zadań rozwojowych - stanowiących społeczne wymagania wobec jednostki, przyjmując ich rozumienie za R. Havighurstem), jak i niejednokrotnie w innych elementach systemu społecznego.

Wyniki przeprowadzonych badań ujawniły związek między społecznymi warunkami edukacji na pograniczu południowym a konstruowaniem tożsamości młodzieży (wartość współczynnika korelacji w badania przeprowadzonych w roku szkolnym 2003/2004 [r=0,682; $p<0,001$ ] wskazuje na umiarkowany związek; korelację wysoką, zależność znaczącą odnotowano w badaniach przeprowadzonych w roku 2016/2017 [r=0,73757 Chi2(1482)=2091,0 p=0000)].

Społeczne warunki edukacji traktować można jako źródła, podstawy, wyznaczniki konstruowania tożsamości młodzieży. Doceniając ich wagę jako swoistego wsparcia jednostki w jej rozwoju trzeba ujmować je i analizować w kontekście pogranicza i jego kapitału społecznego, kulturowego, ludzkiego - jednostek i grup zaangażowanych w ten proces. Odrębność kultury pogranicza, często również religii i wyznania, jest płaszczyzną, w której kształtuje się i rozwija się tożsamość (Janeczek, Szczepański, 2006). Świadomość swoistej genealogii postrzeganej w kategoriach cech biologiczno-rasowych jest obszarem kształtowania się stereotypów dotyczących własnej osoby (płci), ale i innych ludzi. W płaszczyźnie wzajemnego postrzegania siebie, swojej grupy i innych grup rodzą się określone identyfikacje społeczne, są one elementem autoidentyfikacji. Szerokie tło do interpretacji oraz szanse ogólniejszego ujmowania zachowań tożsamościowych na tle złożonych kontekstów kulturowych, politycznych, światopoglądowych, ideologicznych oddziałujących na życie ludzi i wyznaczających ich działania i zachowania daje TZT T. Lewowickiego (1995). Pewną rolę odgrywają obecnie procesy zachodzące w wielu obszarach życia: rynek usług i dóbr, rynek pracy, niski współczynnik bezrobocia, nowe warunki do indywidualnych wyborów; wzbogacenie symbolicznej sfery kultury, różnorodność wzorów życia, które stają się konkurencją dla tych wcześniej wykształconych.

Zaspokojenie potrzeby tożsamości pojawia się jako splot presji czynników biologicznych, psychologicznych, społeczno-kulturowych, nieodłącznie związane jest też z modelem życia społecznego. Każde środowisko tworzy sobie właściwy kontekst dla rozwoju, ma inną sobie właściwą dynamikę przepracowywania zadań rozwojowych. 


\section{KONKLUZJE}

Zarówno codzienne obserwacje, jak i prowadzone badania empiryczne inspirują do nieustannie do poszukiwania uwarunkowań edukacji wspierającej rozwój. Coraz częściej odnajdujemy je w poziomie i standardach życia, zdolności do realizowania wyznaczonych sobie przez młodzież celów i dążeń życiowych.

W tekście tym - w odniesieniu do zadań rozwojowych i pogranicza - podjęłam próbę przedstawienia propozycji pedagogicznej odnoszącej się do konstruowania tożsamości współczesnego młodego pokolenia. Jest to pedagogika ogólna w perspektywie rozwojowej. Stanowi ona, w mojej opinii, konstruktywną odpowiedź na problemy edukacji, pytania i problemy młodych ludzi wypływające i wynikające ze złożonej współczesności i trudnej do zdefiniowania przyszłości.

W moim przekonaniu, popartym własnymi doświadczeniami badawczymi, kategorie zadań rozwojowych i pogranicza stanowią płodne pole analiz. Spinają endo- i egzogenne czynniki rozwoju, wskazują na ich kulturowe umocowania, pozwalają odnieść się jednocześnie do sfery faktów (Jak jest? Kim jest człowiek?), wartości (Jak powinno być? Kim ma być człowiek?), działania (Co i jak robić? Kim się staje człowiek pod wpływem pedagogicznego działania?)9.

Pogranicze odnosi się do ludzkiego uniwersum („wszechświat”, „całokształt czegoś”). To kompleks właściwości takich jak język (gwara, dialekt), religia (wyznania), zachowania tożsamościowe, stereotypy, oświata, kultura, potencjał gospodarczy, kapitał społeczny, kulturowy, ludzki. Wytworzyło ono schematy poznawcze, mechanizmy zachowań tożsamościowych, swoiste praktyki społeczne i to one niezmiennie decydują o społecznych warunkach edukacji oraz o powodzeniu w pokonywaniu problemów rozwojowych - zadań rozwojowych.

Przeprowadzone w dwóch okresach pomiarowych badania i ich wyniki pokazują skutki psychospołeczne i psychokulturowe położenia pogranicznego dla rozwoju młodzieży znajdującej się w okresie przejścia. Wyjaśnień tych spraw, zjawisk może dostarczyć nowa subdyscyplina psychologii rozwijana przez Jolantę Miluską (2016, s. 144) - psychologia społeczno-kulturowego pogranicza, która „,podejmuje tematykę psychologicznego funkcjonowania człowieka, wyznaczonego poprzez miejsce, w którym on żyje (...) ocenia i interpretuje mechanizmy odpowiedzialne za funkcjonowanie psychologiczne mieszkańców pogranicza”.

9 Sfera faktów, wartości i działania do dziedziny refleksji pedagogiki empirycznej, hermeneutycznej i prakseologicznej (Gnitecki, 1994), warto podjąć próbę scalenia tej refleksji w obrębie tych dziedzin. 
Na tle podjętych rozważań dostrzegam potrzebę prowadzenia badań porównawczych, podłużnych na różnych pograniczach (dla ustalenia, czy stwierdzone prawidłowości mają walor ogólny), stosowania nie tylko ilościowych badań sondażowych, ale także jakościowych, by wielostronnie opisywać siłę i zakres występowania opisywanych zjawisk.

\section{Bibliografia}

Bauman, Z. (1996). Socjologia. Tłum. Jerzy Łoziński. 159. Poznań: Wydawnictwo Zysk i S-ka.

Bazielich, B. (red.) (1995). Śląsk - etniczno-kulturowa wspólnota i różnorodność. Wrocław: Wyd. UW.

Beniger, J.R. (1986). The Control Revolution. Cambridge: MA.

Brzezińska, A. (2000). Społeczna psychologia rozwoju. Warszawa: WN Scholar.

Brzezińska, A., Bardziejewska, M., Ziółkowska, B. (red.) (2003). Zagrożenia rozwoju w okresie dorastania. Poznań: Wyd. Fundacji Humaniora.

Castells, M. (1998). End of Millennium. The Information Age: Economy. Society and Culture, 3. Oxford: Blackwell.

Castells, M. (2008). Siła tożsamości. Tłum. Sebastian Szymański. Warszawa: WN PWN.

Cole, L., Hall, I.N. (1964). Psychology of adolescence. New York: Holt, Rinehart and Winston INC.

Cybal-Michalska, A.(2006). Tożsamość młodzieży w perspektywie globalnego świata. Studium socjopedagogiczne. Poznań: WN UAM.

Cybal-Michalska, A. (2013). Młodzież akademicka a kariera zawodowa. Kraków: „Impuls”. Dyczewski, L. (1993). Kultura polska w procesie przemian. Lublin: Towarzystwo Naukowe Katolickiego Uniwersytetu Lubelskiego.

Erikson, E.H. (1994). Identity and the Life Cycle. New York-London: W.W. Norton \& Company.

Erikson, E.H. (2004). Tożsamość a cykl życia. Tłum. M. Żywicki. Poznań: Wyd. Zysk i S-ka.

Ferguson, G.A., Takane, Y. (2004). Analiza statystyczna w psychologii i pedagogice. Tłum. M. Zagrodzki. Warszawa: PWN.

Lewowicki, T. (red.) (1994). Poczucie tożsamości narodowej młodzieży. Studium z pogranicza polsko-czeskiego. Cieszyn: Wyd. UŚ, Filia w Cieszynie.

Janeczek, J., Szczepański, M.S. (red.) (2006). Dynamika ślq̨skiej tożsamości. Katowice: Wyd. UŚ.

Jasiński, Z., Lewowicki, T., Nikitorowicz, J. (red.) (1998). Potencjał społeczno-kulturowy polskich pograniczy. Opole: Wyd. UO.

Frankfort-Nachmias, Ch., Nachmias, D. (2001). Metody badawcze w naukach społecznych. Poznań: Wyd. Zysk i S-ka.

Generations X Y Z and the others. Pobrane z: http://socialmarketing.org/archives/generations-xy-z-and-the-others/ (21.03.2018). 
Gładysz, M. (1972). Z zagadnień procesów kulturowych pogranicza etnicznego. W: Prace Etnograficzne, 6.

Gobal-Klas, T. (2009). Media i komunikowanie masowe. Teorie i analizy prasy, radia, telewizji, Internetu (s. 299). Warszawa: WN PWN.

Golka, L.(2016). Uwagi o efekcie pogranicza. W: J. Miluska, Psychologia społeczno-kulturowego pogranicza. Wstęp do koncepcji i badań. Szczecin: Wydawnictwo Naukowe Wydziału Humanistycznego US MINERWA.

Guilford, J.P. (1960). Podstawowe metody statystyczne w psychologii i pedagogice. Warszawa: PWN.

Hartmann, D., Toguchi Swartz, T. (2007). The New Adulthood? The Transition to Adulthood from the Perspective of Transitioning Young Adults. In: Constructing Adulthood: Agency and Subjectivity in Adolescence and Adulthood Advances in Life Course Research, 11, 253-286. Pobrane z: https://thesocietypages.org/files/2013/03/TheNew-Adulthood-The-Transition-to-Adulthood-from-the-Perspective-of-TransitioningYoung-Adults-1.pdf.

Havighurst, R.J. (1972). Developmental Tasks and Education. New York: David McKay Company, INC.

Havighurst, R.J. (1981). Developmental Tasks and Education. New York-London: Longman.

Havighurst, R.J., Taba, H. (1963). Adolescent character and personality. New York: Science Editions.

Hofstede, G. (2000). Kultury i organizacje. Zaprogramowanie umysłu. Tłum. M. Durska. Warszawa: Polskie Wyd. Ekonomiczne.

https://sjp.pwn.pl/sjp/uniwersum;2579200.html.

Hurlock, E.B. [1960] (1985). Rozwój dziecka. Warszawa: PWN.

Hurrelmann, K. (1994). Struktura społeczna a rozwój osobowości. Wprowadzenie do teorii socjalizacji. Poznań: Wyd. UAM.

Kłoskowska, A. (1983). Kultura masowa. Krytyka i obrona. Warszawa: PWN.

Krzysztofek, K., Szczepański, M.S. (2003). Zrozumieć rozwój. Od społeczeństw tradycyjnych do informacyjnych. Podręcznik socjologii rozwoju społecznego dla studentów socjologii, nauk politycznych i ekonomii. Katowice: Wyd. UŚ.

Lewowicki, T. (1995). O badaniach społeczności pogranicza - od parcjalnych opisów ku elementom Teorii Zachowań Tożsamościowych. W: Nikitorowicz, J. (red.), Edukacja międzykulturowa. W kręgu potrzeb, oczekiwań i stereotypów (s. 13-27). Białystok: Wyd. „Trans Humana”.

Lipok-Bierwiaczonek, M. (1994). Więzi kulturowe pogranicza polsko-czeskiego (Śląsk Cieszyński, Śląsk Opawski, Raciborskie). Katowice: Fundacja Przestrzeni Górnego Śląska.

Malina, A. (2015). Osobowość młodych dorosłych a podejmowanie zadań rozwojowych związanych z rodziną. Polskie Forum Psychologiczne, 20 (4), 559-572.

Matuszak, A., Matuszak, Z. (2011). Celowy dobór próby. General and Profesional Education, 2, 33-39.

Melosik, Z. (2013). Kultura popularna i tożsamość młodzieży. W niewoli władzy i wolności. Kraków: Oficyna Wydawnicza „Impuls”. 
Merton, R.K. (1982). Teoria socjologiczna i struktura społeczna. Tłum. E. Morawska, J. Werenstein-Żuławski (s. 225). Warszawa: PWN.

Miluska, J. (1996). Tożsamość kobiet i mężczyzn w cyklu życia. Poznań: Wyd. UAM.

Miluska, J. (2016). Psychologia społeczno-kulturowego pogranicza. Wstęp do koncepcji i badań (s. 144). Szczecin: Uniwersytet Szczeciński, WN Wydziału Humanistycznego US MINERWA.

Muszyńska, J. (2014). Miejsce i wspólnota. Poczucie wspólnotowości mieszkańców północno-wschodniego pogranicza Polski. Studium pedagogiczne. Warszawa: Wydawnictwo Akademickie „Żak”.

Nikitorowicz, J. (1995). Pogranicze, tożsamość, edukacja międzykulturowa. Białystok: Wyd. „Trans Humana”.

Oleszkowicz, A., Senejko, A. (2017). Dorastanie. W: J. Trempała (red.), Psychologia rozwoju człowieka (s. 258). Warszawa: PWN.

Parsons, T. (1969). Superego a teoria systemów społecznych. W: Struktura społeczna a osobowość (s. 41-59). Warszawa: Państwowe Wydawnictwo Ekonomiczne.

Przetacznik-Gierowska, M., Tyszkowa, M. (2002). Psychologia rozwoju człowieka. zagadnienia ogólne. Warszawa: PWN.

Price, W.F., Crapo, R.H. (2003). Psychologia w badaniach międzykulturowych. Tłum. A. Nowak. Gdańsk: GWP.

Pogranicze. Pobrane z: https://sjp.pwn.pl/sjp/uniwersum;2579200.html (29.06.2018).

Putnam, R. (2008). Samotna gra w kręgle: upadek i odrodzenie wspólnot lokalnych w Stanach Zjednoczonych. Tłum. P. Sadura, S. Szymański. Warszawa: Wydawnictwa Akademickie i Profesjonalne.

Reber, A.S. (2002). Słownik psychologii. Kurcz I., Skarżyńska K. (red. nauk.). Warszawa: Wyd. Naukowe.

Rifkin, J. (2003). Wiek dostępu. Nowa kultura hiperkapitalizamu, w której płaci się za każdq chwilę życia. Wrocław: Wydawnictwo Dolnośląskie.

Rubacha, K. (2008). Metodologia badań nad edukacjq (s. 305-312). Warszawa: Wyd. Akademickie i Profesjonalne.

Sadowski, A. (1992). Pogranicze. Zarys problematyki. Pogranicze. Studia Społeczne, 1. Białystok: Wyd. UW, Filia w Białymstoku.

Soanes, C., Hawker, S. (eds.) (2005). Compact Oxford English Dictionary of Current English. Pobrane z: http://www.askoxford.com/?view=uk.

Szczepański, M.S. (1999). Region pogranicza kulturowego w perspektywie socjologicznej. W: Bukowska-Floreńska I. (red.), Studia etnologiczne i antropologiczne: Kultury regionalne i pogranicza kulturowe a świadomość etniczna, 2. Kultury regionalne i pogranicza kulturowe a świadomość etniczna. Katowice: Wyd. UŚ.

Szczurek-Boruta, A. (2007). Zadania rozwojowe młodzieży i edukacyjne warunki ich wypełniania $w$ środowiskach zróżnicowanych kulturowo i gospodarczo - studium pedagogiczne. Katowice: Wyd. UŚ.

Szczurek-Boruta, A. (2008). „Zadania rozwojowe” jako kategoria pedagogiczna - wykorzystanie i perspektywy (s. 35-48). W: Wawrzyniak-Beszterda R. (red.), Wokół zagadnień wychowania - aspekty teoretyczne i przyczynki empiryczne. Zeszyty Naukowe Młodych 
Pedagogów przy Komitecie Nauk Pedagogicznych Polskiej Akademii Nauk. Poznań: Wydawnictwo Naukowe.

Szczurek-Boruta, A. (2008). Zadania rozwojowe (s. 709-713). W: Pilch T. (red.), Encyklopedia Pedagogiczna XIX wieku. Warszawa: Wydawnictwo Akademickie „Żak”.

Sztompka, P. (1989). Pojęcie struktury społecznej: próba uogólnienia. Studia Socjologiczne, 3.

Sztompka, P. (2002): Socjologia. Analiza społeczeństwa. Kraków: Wyd. „Znak”.

Britannica Editors (2002). The Encyclopedia Britannica. Pobrane z: http://www.britannica. com.

Triandis, H.C. (1991). Psychologia międzykulturowa: rozwój i dokonania. Tłum. A. Bańka. Przegląd Psychologiczny, 34 (1).

Thomas, R.M. (ed.) (1990). The Encyclopedia of Human Development and Education. Theory, Research, and Studies. Santa Barbara: University of California USA.

Thomson, J.B. (2001). Media i nowoczesność. Wrocław: Wyd. Astrum.

Tomaszewski, T. (1966). Aktywność człowieka. W: Maruszewski M., Reykowski J., Tomaszewski T. (red.), Psychologia jako nauka o człowieku. Warszawa: KiW.

Trempała, J., Olejnik, M. (2016). Badanie rozwoju psychicznego człowieka. W: J. Trempała, Psychologia rozwoju człowieka (s. 134-135). Warszawa: WN PWN.

Tyszkowa, M. (1988). Rozwój psychiczny jednostki jako proces strukturacji i restrukturacji doświadczenia. W: Tyszkowa M. (red.), Rozwój psychiczny człowieka w ciq̨gu życia. Zagadnienia teoretyczne i metodologiczne. Warszawa: PWN.

Zuboff, S. Pobrane z: http://www.shoshanazuboff.com/new/about/ (7.04.2018). 